\title{
Pengaruh Model Problem Based Learning terhadap Hasil Belajar Fisika Siswa Materi Fluida Statis di SMA Negeri 6 Palu
}

\author{
Rizky Mardiansa, Yusuf Kendek dan Unggul Wahyono \\ rizkymardiansa@gmail.com \\ Program Studi Pendidikan Fisika FKIP Universitas Tadulako \\ Jl. Soekarno Hatta Km. 9 Kampus Bumi Tadulako Tondo Palu - Sulawesi Tengah
}

\begin{abstract}
Abstrak - Penelitian ini bertujuan untuk mengetahui pengaruh model problem based learning terhadap hasil belajar fisika siswa pada materi fluida statis di X SMA Negeri 6 Palu. Jenis penelitian ini adalah kuasi- eksperimen dengan rancangan equivalent pretest-posttest design. Penentuan sampel dengan pertimbangan tertentu dan berdasarkan rekomendasi guru kemudian terpilih dua kelas yaitu kelas X MIA 1 dengan jumlah 25 siswa sebagai kelas eksperimen dan kelas X MIA 2 dengan jumlah 24 siswa sebagai kelas kontrol. Instrumen penelitian adalah tes hasil belajar berbentuk pilihan ganda sebanyak 24 soal yang telah divalidasi oleh ahli kemudian dilakukan validitas item dan diperoleh 20 soal. Hasil pengolahan data diperoleh rerata skor posttest kelas eksperimen sebesar 73,80 dan rerata skor kelas kontrol yang diperoleh sebesar 60. Analisis data dilakukan dengan teknik statistik uji-t dua pihak untuk mengetahui pengaruh rerata skor terhadap hasil belajar siswa. Berdasarkan hasil analisis diperoleh nilai $t_{\text {hitung }}=4,33$ lebih besar dari dari $t_{\text {tabel }}=1,67$. Hal tersebut menunjukkan bahwa $t_{\text {hitung }}$ barada diluar daerah penerimaan $\mathrm{H}_{0}$.
\end{abstract}

Kata Kunci: Model problem based learning, Hasil Belajar Fisika

\section{PENDAHULUAN}

Fisika adalah ilmu pengetahuan yang paling mendasar karena berhubungan dengan perilaku dan struktur benda. Namun, banyak siswa yang mengalami kesulitan dalam mempelajari dan memahami konsep fisika. Bentuk kesulitan tersebut dapat berupa kesulitan dalam penyelesaian soal, sehingga menyebabkan rendahnya hasil belajar fisika siswa. [1]

Sederet usaha yang dilakukan pemerintah pada kenyataannya ternyata belum mampu meningkatkan kualitas pendidikan. Kualitas pendidikan masih jauh dari harapan. Mutu pendidikan kita khususnya pada bidang studi fisika belum mencapai hasil ang maksimal, hal tersebut disebabkan oleh siswa jarang melihat fenomena nyata atau media yang berhubungan dengan materi yang dibahas. Sebagian besar materi dan penyampaian materi bersifat berpusat pada buku, siswa jarang diajak untuk melihat langsung kejadian atau fenomena yang nyata ataupun media- media yang representative dengan fenomena yang berkaitan. Hal ini membuat siswa kurang memahami materi pelajaran yang disampaikan, sehingga siswa kurang termotivasi untuk mempelajarinya. [2]

Topik yang penting dalam proses pengajaran dan pembelajaran Fisika adalah bagaimana membantu siswa meningkatkan dan menerapkan pembelajaran tersebut. Maka dari itu, untuk memberikan pengalaman pembelajaran yang memungkinkan siswa untuk terlibat secara aktif dalam pemberian materi saat siswa bekerja sama dengan sesama untuk menerapkan konsep dalam konteks kehidupan nyata yang menjadi tantangan yang dihadapi oleh seorang guru Matematika. Beberapa siswa menggunakan banyak waktu dan usaha di setiap bab pelajaran Matematika, dapat mengatasi sebagian kecil tes penilaian. Namun, mereka tidak mempunyai kemampuan untuk mengintegrasikan pelajaran konsep. [3]

Seorang guru dianjurkan untuk menggunakan sebuah metode yang dimana dapat mengeksplorasikan pemikiran kreatif siswa dan siswa dapat didorong untuk menjadi inovatif sehingga dapat mengeluarkan produk atau hasil yang kreatif. Siswa dapat dimotivasi untuk berpartisipasi dalam proses pembelajaran yang dapat memungkinkan mereka untuk mengetahui bagaimana materi dapat mereka pahami, belajar, dan memecahkan masalah pembelajaran. Jalan pemikiran ini juga dapat melibatkan siswa dalam proses belajar mengajar melalui evaluasi tentang apa yang sering terjadi selama pembelajaran dan dapat dijadikan sebagai jendela dalam proses berpikir siswa. [4]

Didalam mewujudkan berbagai tujuan untuk seorang siswa pada proses pembelajaran, diperlukan sebuah model pembelajaran yang efektif. Salah satunya adalah model pembelajaran berbasis masalah. Model pembelajaran berbasis masalah merupakan model pembelajaran berpusat pada siswa (student-centered) yang banyak dikembangkan akhir- akhir ini. Model pembelajaran berbasis masalah adalah suatu model pembelajaran yang menggunakan masalah dunia nyata sebagai suatu konteks bagi siswa 
p-ISSN 2338-3240, e-ISSN 2580-5924

untuk belajar tentang cara berpikir kritis untuk memperoleh pengetahuan dan konsep yang esensial dari materi pelajaran.

Setelah dilakukan pengamatan di SMA Negeri 7 Palu, khususnya kelas $X$ dalam pembelajaran fisika menggunakan metode ceramah sehingga menimbulkan kejenuhan, siswa menjadi kurang aktif, dan berdampak pada hasil belajar yang kurang maksimal. Tuntutan siswa yang aktif dalam proses pembelajaran di kelas masih kurang diterapkan. Pengenalan simulasi komputer terhadap siswa dalam proses pembelajaran dapat menjadi opsi untuk peningkatan minat dan hasil belajar siswa. Berdasarkan beberapa hasil tulisan diatas sehingga peneliti tertarik untuk melakukan suatu penelitian mengenai model pembelajaran berbasis masalah. Sehingga, peneliti melakukan penelitian dengan melihat pengaruh dari model pembelajaran berbasis masalah dengan desain kreatif terhadap hasil belajar fisika pada siswa kelas X SMA Negeri 7 Palu.

\section{METODE PENELITIAN}

Penelitian yang digunakan adalah jenis penelitian dengan rancangan eksperimen kuasi (quasi-experimental design)

Desain penelitian yang digunakan yaitu the equivalent control group design. Desain penelitian yang digunakan dapat dilukiskan seperti pada Tabel $1^{[5]}$.

\begin{tabular}{lccc}
\multicolumn{4}{c}{ TABEL 1. DESAIN PENELITIAN } \\
\hline Kelompok & $\begin{array}{l}\text { Pra } \\
\text { tes }\end{array}$ & Perlakuan & Pascates \\
\hline $\begin{array}{l}\text { Kelas } \\
\text { Eksperimen }\end{array}$ & $\mathrm{O}$ & $\mathrm{X}$ & $\mathrm{O}$ \\
$\begin{array}{l}\text { Kelas } \\
\text { Kontrol }\end{array}$ & $\mathrm{O}$ & & $\mathrm{O}$ \\
\hline
\end{tabular}

\section{Keterangan:}

$X \quad$ : Model problem based learning

O : Tes awal dan tes akhir

Penelitian dilakukan di SMA Negeri 6 Palu. Populasi dalam penelitian ini adalah seluruh siswa kelas $X$ SMA Negeri 6 Palu tahun pelajaran 2016/2017 yang terdiri dari 10 kelas. Sampel dalam penelitian ini adalah kelas X MIA 1 yang berjumlah 25 siswa dan X MIA 2 yang berjumlah 24 siswa. Teknik pengumpulan sampel yang digunakan adalah purposive sampling, yaitu teknik penentuan sampel dengan pertimbangan tertentu dan berdasarkan rekomendasi guru.

Instrumen yang digunakan dalam penelitian ini adalah tes pilihan ganda untuk melihat hasil belajar siswa pada mata pelajaran fisika yang telah divalidasi oleh validator ahli. Analisis data dilakukan dengan menganalisis instrumen terlebih dahulu menggunakan uji validitas item dan reliabilitas tes yang kemudian dengan menganalisis data hasil penelitian menggunakan uji normalitas, uji homogenitas dan uji hipotesis.

\section{HASIL DAN PEMBAHASAN}

\section{A. Hasil Penelitian}

Adapun instrumen yang diujikan terdiri atas 24 item soal. Uji coba dilakukan dengan tujuan untuk mengetahui validitas, reliabilitas, daya pembeda dan tingkat kesulitan dari instrumen tersebut.

Preetest digunakan untuk mengetahui kemampuan awal siswa sebelum mengikuti pembelajaran. Hasil pengolahan data preetest dan posttest untuk masing-masing kelas, yaitu kelas eksperimen dan kelas kontrol, diperoleh nilai maksimum, nilai minimum, nilai rata-rata dan simpangan baku seperti terlihat pada Tabel 2.

TABEL 2. DESKRIPSI SKOR TES HASIL BELAJAR FISIKA UNTUK KELAS EKSPERIMEN DAN KELAS KONTROL

\begin{tabular}{lcccc}
\hline & \multicolumn{2}{c}{ Preetest } & \multicolumn{2}{c}{ Posttest } \\
\cline { 2 - 5 } Uraian & Eksperimen & Kontrol & Eksperimen & Kontrol \\
\hline $\begin{array}{l}\text { Sampel (n) } \\
\text { Nilai }\end{array}$ & 25 & 24 & 25 & 24 \\
$\begin{array}{l}\text { maksimum } \\
\text { Nilai }\end{array}$ & 55 & 50 & 95 & 75 \\
$\begin{array}{l}\text { minimum } \\
\text { Skor rata- }\end{array}$ & 10 & 10 & 50 & 35 \\
$\begin{array}{l}\text { rata } \\
\text { Standar } \\
\text { deviasi }\end{array}$ & 11,33 & 29,17 & 73,8 & 60 \\
\hline
\end{tabular}

Uji normalitas pada penelitian ini menggunakan uji Chi-kuadrat dengan kriteria penerimaan $\chi^{2}$ Hitung $<\chi^{2}$ tabel, taraf signifikansi $a=$ 0,05 dan derajat kebebasan $\mathrm{dk}=\mathrm{k}-3$. Berdasarkan hasil perhitungan untuk posttest nilai $\chi^{2}$ hitung untuk kelas eksperimen adalah sebesar 6,44 dan untuk kelas kontrol sebesar 4,14 dengan $\chi^{2}$ tabel sebesar 7,81.Data tersebut disajikan pada tabel 3 .

TABEL 3. HASIL UJI NORMALITAS POSTTEST KELAS EKSPERIMEN DAN KELAS KONTROL

\begin{tabular}{lllll}
\hline No. & Kelas & $\begin{array}{l}\text { Nilai } \\
\mathrm{X}^{2} \text { Hitung }\end{array}$ & $\begin{array}{l}\text { Nilai } \\
\mathrm{X}^{2} \text { Tabel } \\
=0,05)\end{array}$ & Keputusan \\
\hline 1 & $\begin{array}{l}\text { Kelas } \\
\text { Eksperimen } \\
\text { Kelas } \\
\text { Kontrol }\end{array}$ & 6,44 & 7,81 & $\begin{array}{l}\text { Terdistribusi } \\
\text { normal }\end{array}$ \\
\hline
\end{tabular}

Berdasarkan hasil uji normalitas yang ditunjukkan pada Tabel 3 dapat diketahui nilai $\mathrm{X}^{2}$ Hitung $<\mathrm{X}^{2}$ tabel sehingga dapat disimpulkan keduanya berasal dari populasi yang terdistribusi normal. 
p-ISSN 2338-3240, e-ISSN 2580-5924

Uji homogenitas pada penelitian ini menggunakan uji statistik Fisher (Uji F) dengan taraf signifikansi $a=0,05$. Uji homogenitas dilakukan untuk melihat apakah data berasal dari varians yang sama atau tidak.

TABEL 4. HOMOGENITAS DUA VARIANS TES AKHIR (POSTTEST) KELAS EKSPERIMEN DAN KELAS KONTROL.

\begin{tabular}{|c|c|c|c|c|c|}
\hline No. & Kelas & $\begin{array}{l}\text { Nilai } \\
\text { varians }\end{array}$ & $\begin{array}{l}\text { Varians } \\
\text { hitung }\end{array}$ & $\begin{array}{l}\begin{array}{l}\text { Nilai } F \\
\text { table } \\
(a \\
0,05)\end{array}=\end{array}$ & Keputusan \\
\hline 1 & $\begin{array}{l}\text { Kelas } \\
\text { Ekperimen } \\
\text { Kelas } \\
\text { Kontrol }\end{array}$ & $\begin{array}{l}11,79 \\
10,45\end{array}$ & 1,27 & 2,00 & $\begin{array}{l}\text { Kedua } \\
\text { data } \\
\text { homogen }\end{array}$ \\
\hline
\end{tabular}

Berdasarkan hasil uji homogenitas pada Tabel 4 dengan taraf signifikansi $(a=0,05)$, dari data tersebut terlihat bahwa Fhitung lebih kecil dari

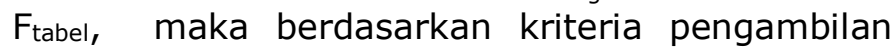
keputusan dapat disimpulkan bahwa tidak terdapat perbedaan varians antara kelas eksperimen dan kelas kontrol atau dengan kata lain varians antara kelas eksperimen dan kelas kontrol adalah sama atau homogen.

Uji hipotesis dilakukan setelah diperoleh bahwa data hasil belajar antara kelas ekperimen dan kelas kontrol berdistribusi normal dan homogen. Uji ini digunakan untuk memastikan apakah hipotesis yang dilakukan dapat diterima atau tidak. Uji t tersebut diperoleh berdasarkan data tes akhir. Hasil dapat dilihat pada Tabel 5.

TABEL 5. UJI HIPOTESIS (DUA PIHAK) TES AKHIR KELAS EKSPERIMEN DAN KELAS KONTROL

\begin{tabular}{clcccc}
\hline No. & Kelas & $\begin{array}{c}\text { Nilai } \\
\text { rata-rata } \\
(\bar{X})\end{array}$ & $\mathrm{t}_{\text {hitung }}$ & $\begin{array}{c}\mathrm{t} \\
\text { table }\end{array}$ & Keputusan \\
\hline 1 & $\begin{array}{l}\text { Kelas } \\
\text { Eksperimen }\end{array}$ & 73,8 & & & $\mathrm{H}_{1}$ \\
2 & $\begin{array}{l}\text { Kelas } \\
\text { Kontrol }\end{array}$ & 60 & 4,33 & 1,67 & diterima \\
\hline
\end{tabular}

Uji t yang digunakan untuk hipotesis ini adalah uji-t dua pihak. Uji ini digunakan untuk memastikan apakah hipotesis yang diajukan dapat diterima atau ditolak.

Kriteria $\mathrm{H}_{0}$ diterima jika thitung $<t_{\text {tabel }}$ dan $\mathrm{dk}=$ $\left(n_{1}+n_{2}-2\right)=25+24-2=47$ pada taraf nyata $\mathrm{a}=0,05$, untuk harga $\mathrm{t}$ lainnya $\mathrm{H}_{0}$ ditolak. Dari daftar distribusi diperoleh tabel $=1,67$ sedangkan dari hasil perhitungan uji-t diperoleh nilai thitung $=$ 1,45 yang berada di daerah penerimaan $\mathrm{H}_{0}$. Hal ini berarti thitung $<t_{\text {tabel }}=1,45<1,67$; dengan demikian $\mathrm{H}_{0}$ di terima dalam taraf nyata $\mathrm{a}=0,05$ dan $\mathrm{H}_{1}$ diterima. Dengan demikian $\mathrm{H}_{1}$ ditolak dan $\mathrm{H}_{0}$ diterima. Hal ini menyatakan bahwa sebelum diberi perlakuan tidak terdapat perbedaan hasil belajar antara kelas yang diberi perlakuan problem based learning dengan model konvensional. Dan pada uji hipotesis akhir menunjukan bahwa thitung $>$ ttabel yaitu 4,33 > 1,67 yang menyatakan bahwa setelah diberi perlakuan terdapat perbedaan hasil belajar siswa antara kelas yang diberi perlakuan menggunakan model problem based leaning dengan model konvensional.

\section{B. Pembahasan}

Penelitian ini bertujuan untuk mengetahui pengaruh model problem based learning dengan terhadap hasil belajar fisika siswa pada materi fluida statis kelas di SMA Negeri 6 Palu. Kegiatan pembelajaran dilakukan sebanyak 5 kali pertemuan terdiri dari 3 kali tatap muka di kelas dan 2 kali pertemuan untuk pretest dan postest di kedua kelas baik kelas eksperimen maupun kelas kontrol. Pada penelitian ini, yang membedakan antara kelas eksperimen dan kelas control yaitu pada kelas eksperimen diberikan perlakuan dengan menggunakan model problem based learning dan pada kelas kontrol menggunakan model konvensional.

Berdasarkan hasil anallisis pretest data berdistribusi normal dan memiliki varians yang homogen, kemudian dilakukan uji statistik dan didapatkan bahwa hasil belajar fisika tidak berbeda, kelompok siswa yang mengikuti model problem based learning sama hasil belajarnya dibandingkan dengan kelompok siswa yang mengikuti model konvensional.

Analisis data pretest dan posttest bertujuan untuk mengetahui ada tidaknya pengaruh hasil belajar fisika antara kelompok siswa yang mengikuti model problem based learning dengan kelompok siswa yang mengikuti model konvensional pada kelas X SMA Negeri 6 Palu. Setelah dianalisis, data posttest berdistribusi normal dan memiliki varians yang homogen, kemudian dilakukan uji statistik dan didapatkan bahwa hasil belajar fisika berbeda, kelompok siswa yang mengikuti model problem based learning lebih tinggi hasil belajarnya dibandingkan dengan kelompok siswa yang mengikuti model konvensional.

Selanjutnya kemampuan akhir dari hasil posttest pada kelas eksperimen memiliki skor rata- rata 73,8 dan kelas kontrol dengan skor 60 . Sehingga kelas eksperimen dalam pembelajaran menggunakan model pembelajaran problem based learning memiliki hasil belajar yang lebih tinggi dibanding kelas kontrol yang dalam pembelajaran menggunakan model pembelajaran konvensional.

Berdasarkan hasil perhitungan, hasil uji normalitas pretest dan posttest kelas eksperimen dan kelas kontrol keduanya berdistribusi normal karena memenuhi kriteria penerimaan $X^{2}$ hitung $<$ 
$\mathrm{X}^{2}$ tabel. Selanjutnya hasil uji homogenitas disimpulkan bahwa tidak terdapat perbedaan varians antara kelas eksperimen dan kelas kontrol atau dengan kata lain kedua kelas dikatakan homogen.

Selanjutnya, untuk melihat perbedaan hasil belajar siswa menggunakan uji perbedaan ratarata. Sebelum melakukan uji perbedaan syarat yang harus dipenuhi adalah data harus berdistribusi normal dan homogen. Oleh karena data yang diperoleh dari perhitungan terdistribusi normal dan homogen, maka dilakukan uji perbedaan rata- rata menggunakan uji-t (dua pihak). Tabel 4.4 menunjukkan bahwa nilai thitung $=4,33>t_{\text {tabel }}=1,67$. Sesuai dengan kriteria penerimaan, maka dapat dikatakan bahwa ratarata hasil belajar antara siswa kelas eksperimen lebih baik daripada kelas kontrol. Dengan demikian $\mathrm{H}_{0}$ ditolak dan $\mathrm{H}_{1}$ diterima hal ini menunjukkan bahwa terdapat pengaruh yang signifikan antara rata- rata nilai kelas eksperimen dan kelas kontrol.

Pada Tahapan awal guru mengorientasi siswa pada masalah, dimana siswa mendengarkan penjelasan guru mengenai tujuan pembelajaran kemudian memperhatikan dan mendegarkan pertanyaan yang diberikan guru serta mencoba untuk menjawab pertanyaan tersebut. Pada tahap kedua yaitu mengorganisasikan siswa untuk belajar, dimana guru mengorganisasikan kegiatan belajar dengan membagi siswa kedalam kelompok- kelompok kecil (4-5 orang tiap kelompok) kemudian guru membagikan LKS untuk dikerjakan kelompok yang telah dibuat sebelumnya.

Pada tahap ketiga yaitu membimbing penyelidikan individu maupun kelompok, dimana guru membimbing siswa untuk mengumpulkan informasi yang sesuai untuk mendapatkan penjelasan dan pemecahan masalah. Pada tahap ke empat yaitu mengembangkan dan menyajikan hasil karya, dimana guru membantu siswa dalam merencanakan dan menyiapkan karya berupa laporan serta membantu mereka untuk berbagi tugas dengan temannya. Guru mempersilahkan masing- masing kelompok untuk mempersentasikan hasil dari pekerjaannya. Guru bersama siswa melihat persamaan dan perbedaan yang ada. Peran guru sangat dibutuhkan sebagai fasilitator untuk menangkap jawaban yang disepakati bersama.

Pada tahap terakhir yaitu menganalisis dan mengevaluasi proses pemecahan masalah, dimana guru membantu siswa untuk melakukan refleksi dan evaluasi terhadap laporan dari hasil diskusi kelompok siswa yang telah dipresentasikan. Siswa berbagi solusi atas masalah yang dipecahkan melalui presentasi dan memberikan tanggapan atas solusi yang disampaikan kelompok lain untuk dikoreksi.

Hasil penelitian ini sejalan dengan penelitian yang dilakukan oleh Susanti dan Gunawan (2013) dalam tulisannya yang berhasil menunjukkan bahwa penerapan model pembelajaran berbasis masalah berbantuan simulasi komputer pada materi fluida dinamis dapat meningkatkan penguasaan konsep dan keterampilan berpikir kritis siswa. Triyuningsih (2011) dalam penelitiannya juga berhasil menunjukkan bahwa penerapan model pembelajaran berbasis masalah berbantuan simulasi komputer pada materi fluida dinamis dapat meningkatkan penguasaan konsep dan keterampilan berpikir kritis siswa. Sari dan Tarigan (2014) juga menunjukkan bahwa ada perbedaan akibat pengaruh model pembelajaran berbasis masalah berbantuan komputer terhadap hasil belajar siswa. Untuk hubungan kem ampuan berpikir kritis dan hasil belajar siswa, diperoleh kesimpulan bahwa terdapat hubungan yang positif antara kemampuan berpikir kritis dan hasil belajar siswa pada kelas eksperimen maupun kelas kontrol.

Berdasarkan semua data yang telah dijabarkan dapat dinyatakan bahwa, terdapat pengaruh model pembelajaran problem based learning terhadap hasil belajar fisika pada siswa kelas $X$ SMA Negeri 6 Palu. Peningkatan hasil belajar tersebut terjadi karena selama proses pembelajaran siswa di tuntut untuk memecahkan masalah yang diberikan.

\section{KESIMPULAN DAN SARAN}

Hasil penelitian ini diperoleh kesimpulan bahwa terdapat pengaruh model problem based learning terhadap hasil belajar fisika pada siswa kelas $X$ SMA Negeri 6 Palu. Hal ini ditunjukkan sesuai hasil pengujian hipotesis dimana nilai thitung $=4,33$ $>$ tabel $=1,67$. Hasil $u j i$ hipotesis ini memperlihatkan bahwa harga thitung tidak berada di dalam daerah penerimaan Ho atau dengan kata lain $\mathrm{H}_{1}$ diterima, yang berarti terdapat pengaruh model pembelajaran berbasis masalah dengan terhadap hasil belajar fisika siswa.

\section{DAFTAR PUSTAKA}

[1] Giancoli, dan Douglas C. (2001). Fisika Jilid I. (Edisi ke5). Jakarta : Erlangga.

[2] Mahendra, Kd., Sumantri, Md., dan Margunayasa, Gd. (2014)."Pengaruh Model Pembelajaran Berbasis Masalah Terhadap Hasil Belajar IPA Siswa Kelas V SD". e-Journal Mimbar PGSD. 2, (1), 1-10.

[3] Chen, W.H. (2013). "Applying Problem-Based Learning Model and Creative Design to Conic-Sections Teaching". International Journal of Education and Information Technologies. Vol 7.

[4] Awang, dkk (2008). "Creative Thinking Skill Approach Through Problem-Based Learning : Pedagogy dan 
Practice in the Engineering Classroom". International Journal of Social, Behavioral, Educational, Economic, Business and Industrial Engineering. Vol : 2 No : 4.
[5] Sugiyono, (2014). Metode Penelitian Kuantitatif, Penelitian Kualitatif, dan $R \& D$. Bandung: Alfabeta. 